\section{Simple Sequence Repeat Identification and Endocarp Characterization of Olive Tree Accessions in a Tunisian Germplasm Collection}

\author{
Mahdi Fendri \\ Dpto. de Bioquímica, Biología Celular y Molecular de Plantas, Estación \\ Experimental del Zaidín (CSIC), C/Profesor Albareda, 1, 18008 Granada, Spain
}

Isabel Trujillo

Dpto. de Agronomía, Universidad de Córdoba, Ctra. Madrid, Km. 396, 14071

Córdoba, Spain

\author{
Ahmed Trigui \\ Institut de l'Olivier, P.O. Box 1087, 3018 Sfax, Tunisia
}

María Isabel Rodríguez-García

Dpto. de Bioquímica, Biología Celular y Molecular de Plantas, Estación Experimental del Zaidín (CSIC), C/Profesor Albareda, 1, 18008 Granada, Spain

\section{Juan de Dios Alché Ramírez ${ }^{1}$ \\ Dpto. de Bioquímica, Biología Celular y Molecular de Plantas, Estación Experimental del Zaidin (CSIC), C/Profesor Albareda, 1, 18008 Granada, Spain}

Additional index words. microsatellite markers, Olea europaea, characterization, varieties

\begin{abstract}
Most traditional olive-producing countries possess a diversified genetic patrimony in Olea europaea L. Since the emergence of modern olive growing system, the identification, classification, and conservation of autochthonous olive cultivars is a priority for these countries. In this work, a total of 84 accessions belonging to the "Boughrara"-Sfax olive germplasm collection located in Tunisia have been screened using a powerful set of eight simple sequence repeat markers (SSRs). The study revealed a high genetic variability among the collection and detected a total of 64 alleles. For better management of the mentioned germplasm bank, an improved classification of the entries, including new denominations, has been proposed. In addition, several cases of mislabeling, synonymy, and homonymy have been clarified. Genetic relationships among cultivars have been analyzed showing four major clusters. Finally, a correspondence factor analysis demonstrated that cultivars tend to cluster depending on their main use as oil or table olives. No clear clustering tendencies were observed when the geographical origin of cultivars was used as the criteria for the analysis. All results obtained by SSR screening and classification were in accordance with classification based on morphological traits of fruit endocarps.
\end{abstract}

Received for publication 22 Apr. 2010. Accepted for publication $10 \mathrm{Aug} .2010$.

This research has been supported by FEDER cofunded Projects BFU 2004-00601/BFI, BFU200800629, and Junta de Andalucía P06-AGR-01791. Research carried out by M. Fendri was funded by AECID.

Contribution from the Department of Biochemistry, Cell and Molecular Biology of Plants, "Estación Experimental del Zaidín" Granada (Spain) and the Department of Agronomy, University of Córdoba, Córdoba (Spain).

We are grateful to the "Institut de l'olivier" Sfax (Tunisia) for providing the plant material used in the study. Special thanks are due to Drs. C. Muñoz Díez, R. De la Herrán, and A. Hamman-Khalifa for their help analyzing simple sequence repeats.

${ }^{1}$ To whom reprint requests should be addressed; e-mail juandedios.alche@eez.csic.es.
(Rallo et al., 2005), Tunisia includes diversified genetic resources, which are mainly formed by small distributed autochthonous cultivars. The characterization of this diversity is essential for the better management of the national germplasm and for genetic breeding programs.

The classical approach in the identification of olive cultivars has been based on agronomical and/or morphological studies. It consists of measures such as production average, precocity, vigor, etc. and the direct observation of several distinctive traits on branches, fruits, endocarps, leaves, and inflorescences (Barranco and Rallo, 1984; Barranco et al., 2005). Among the aforementioned morphological characters, endocarps are considered one of the most discriminative traits. These traits are highly inheritable, have low sensitivity to environmental conditions, and are easily observed on collected and stored material (Rallo et al., 2005). A number of analyses has been conducted on Tunisian germplasm material from different regions of the country using morphological and/or agronomical characters (Mehri et al., 1997; Taamalli et al., 2006; Trigui et al., 2002). Several collections of olive cultivars have been created in Tunisia. Among them, the "Boughrara"-Sfax olive germplasm collection is considered the most important in terms of cultivar numbers. Although the morphological and agronomical studies are very useful for both exploration surveys (Barranco et al., 2000, 2005; Barranco and Rallo, 1984; Cimato et al., 1993) and germplasm bank characterization (Caballero et al., 2006), results can be influenced by several non-genetic factors. As a consequence, molecular methods are very suitable to reach a better understanding of the material's genetic diversity.

Molecular studies have started with the use of isoenzyme markers (Ouazzani et al., 1993; Trujillo et al., 1995) and at a later stage have been carried out using DNA markers as restriction fragment length polymorphisms (Besnard et al., 2001a), random amplified polymorphic DNAs (Belaj et al., 2001; Fabbri et al., 1995), amplified fragment length polymorphisms (Angiolillo et al., 1999) and microsatellite markers [simple sequence repeats (SSRs)] (Baldoni et al., 2009; La Mantia et al., 2005).

The microsatellite technique is one of the most reliable methods used in olive cultivar characterization. It has revealed a high informative level because the markers are polymorphic, multiallelic, and codominant. Moreover, it consists of a relatively simple methodology that permits an easy interpretation of results (Rafalski et al., 1996). SSR markers have been successfully used in germplasm bank classification and contributed to better management of several olive collections around the world (Khadari et al., 2003; Muzzalupo et al., 2006). To provide a better worldwide applicable tool for olive DNA typing, a list of 11 SSR markers has been recently selected among 37 microsatellites available for olive cultivar characterization. The mentioned list has been based on the reproducibility, quality of scoring, information content, independent segregation, 
and discriminative capacity of the markers (Baldoni et al., 2009).

Some studies using microsatellite markers have been achieved on Tunisian cultivars. They have been carried out in olive trees belonging to different collections (Taamalli et al., 2008), on trees of commercial interest original from different geographical regions of Tunisia (Rekik et al., 2008), or to study the differences between cultivated varieties of olive and Oleaster trees mainly from the northern region of the country (Hannachi et al., 2008).

The present work aims to identify and classify 84 olive accessions obtained by a national exploration survey and introduced in the "Boughrara"-Sfax olive germplasm collection (South of Tunisia). The work has been carried out using eight microsatellite markers, seven of them mentioned as some of the most reliable existing microsatellite markers for olive cultivar characterization (Baldoni et al., 2009). Furthermore, this work emphasizes the possibility of integration of both molecular and morphological approaches for germplasm classification because endocarp traits have been used to corroborate all conclusions obtained by the SSR screening.

Table 1. Morphological characters of the endocarps on 84 analyzed accessions.

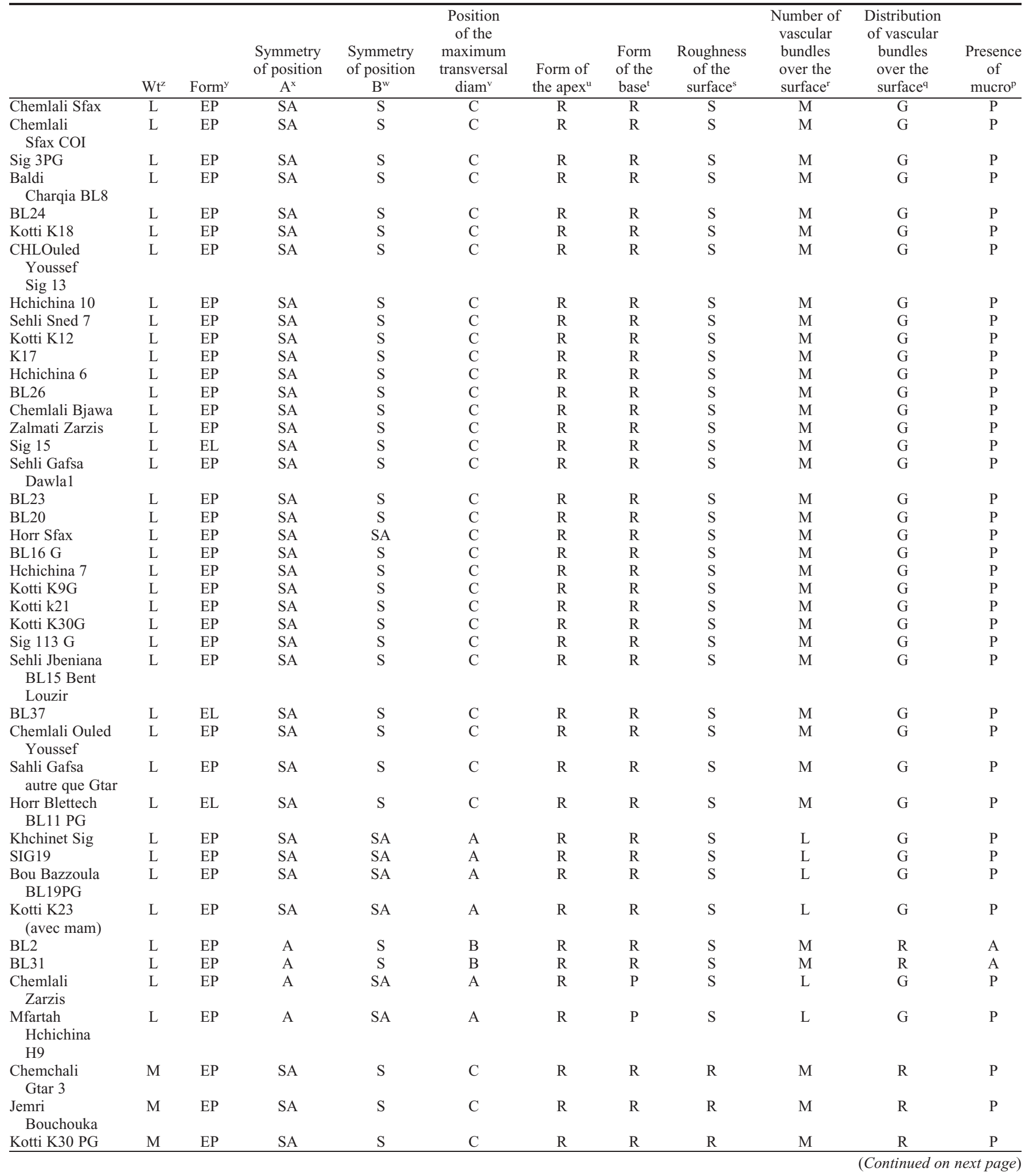




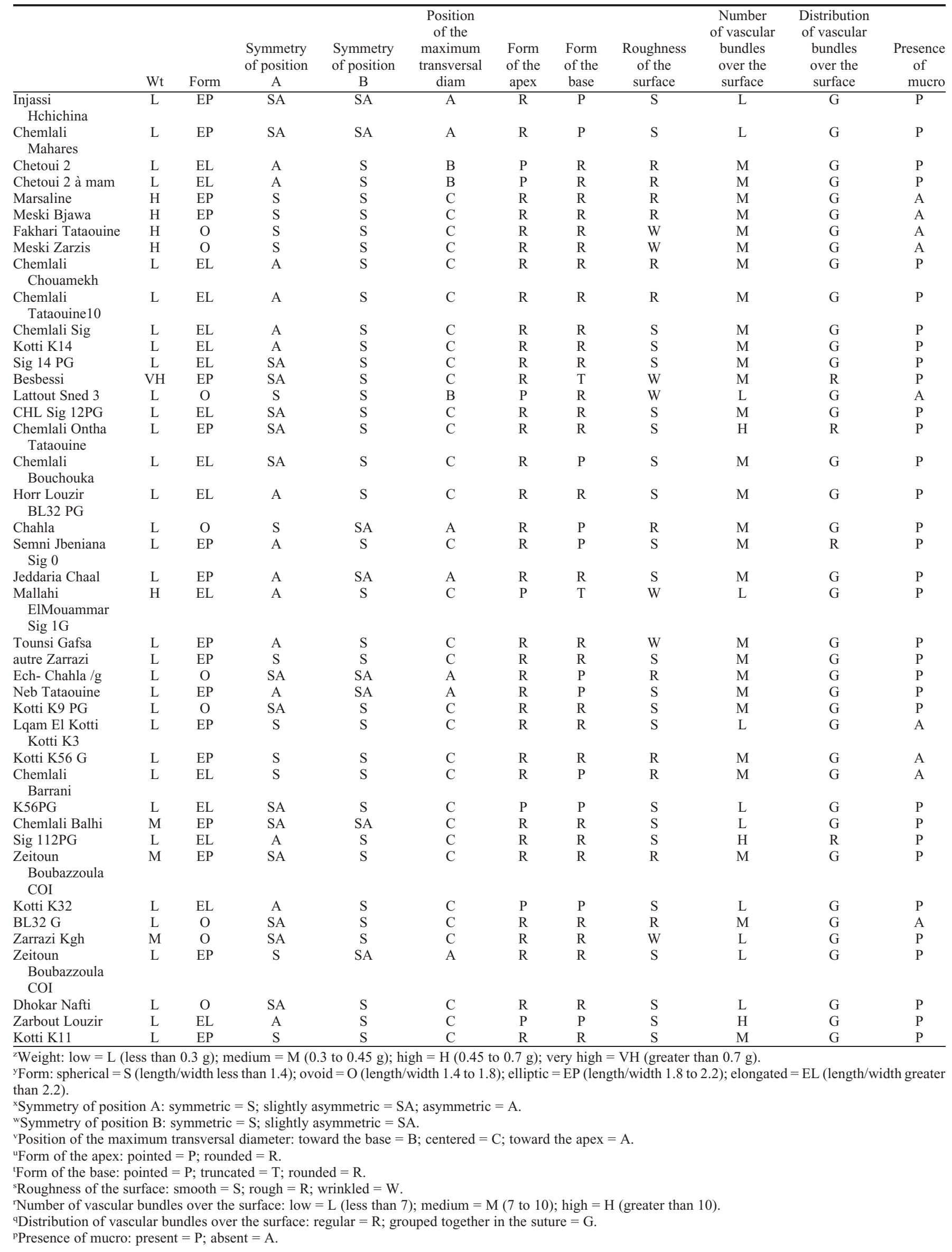




\section{Material and Methods}

Plant material and DNA extraction. Samples from 84 accessions were obtained from the national olive collection: "Conservatoire National de l'Olivier de 'Boughrara'-Sfax" (south of Tunisia: long. $34^{\circ} 59^{\prime} 05^{\prime \prime} \mathrm{N}$, lat. $10^{\circ} 32^{\prime} 56^{\prime \prime}$; elevation: $125 \mathrm{~m}$ ). Total genomic DNA was isolated from fresh, young leaves following a CTAB protocol originally developed by Murry and Tompson (1980) and further modified by De la Rosa et al. (2002).

Microsatellite assay. A set of eight microsatellite markers (ssrOeUA-DCA3, ssrOeUADCA9, ssrOeUA-DCA15, ssrOeUA-DCA16, ssrOeUA-DCA18, GAPU71B, GAPU101, and UDO99-043) were selected (Carriero et al., 2002; Cipriani et al., 2002; Sefc et al., 2000). The majority of the selected markers has been described to be very efficient for olive cultivar identification and population genetic studies (Baldoni et al., 2009). Polymerase chain reactions (PCRs) were carried out in a T-Gradient Thermoblock (Biometra, Goettingen, Germany) thermal cycler in a total volume of $20 \mu \mathrm{L}$ containing $5 \mathrm{ng}$ of genomic DNA, $1.5 \mathrm{mM} \mathrm{MgCl}_{2}, 60 \mu \mathrm{M}$ dNTPs, $0.028 \mathrm{U} / \mu \mathrm{L}$ Taq polymerase (Biotools, Madrid, Spain), $0.2 \mu \mathrm{M}$ forward primer (either FAM, HEX, or $\mathrm{NED}$ fluorescently labeled), and $0.2 \mu \mathrm{M}$ of the corresponding unlabelled reverse primer. PCR steps were: initial denaturation at $95^{\circ} \mathrm{C}$ for 5 min, 35 cycles with three steps: of $95^{\circ} \mathrm{C}$ for $20 \mathrm{~s}$ (denaturation), 50 to $52^{\circ} \mathrm{C}$ depending on the primers combination for $30 \mathrm{~s}$ (annealing), and $72{ }^{\circ} \mathrm{C}$ for $30 \mathrm{~s}$ (extension). A final extension step of $72{ }^{\circ} \mathrm{C}$ for 8 min was carried out. PCR products were separated in an automatic capillary sequencer, ABI PRISM 3100-AVANT GENETIC ANALYSER (Applied Biosystems/ Hitachi, Tokyo, Japan), using a definite size marker: GeneScan-500 ROX Size Standard (Applied Biosystems, Warrington, U.K.).

Data analysis. Amplified fragments were analyzed and scored using the GENEMAPPER 3.0 and GENOTYPER 3.7 software (Applied Biosystems). Both the expected and the observed heterozygosity $\left(\mathrm{H}_{\mathrm{E}} / \mathrm{H}_{\mathrm{O}}\right)$ indices were calculated by using the CERVUS 3.0 software (Marshall et al., 1998) according to the equilibrium law of Hardy-Weinberg (Nei, 1987) as well as the polymorphic information content (PIC) (Botstein et al., 1980) and the frequency of null alleles (Pemberton et al., 1995). The probability of identity (Waits et al., 2001) was computed by using the GIMLET 1.3.3 program (Valiere, 2002). The genetic relationships among the identified cultivars and the cophenetic correlations were analyzed by NTSYSPC 2.02 software (Rohlf, 1998) using the DICE coefficient and the unweighted pair group method with arithmetic mean (UPGMA) (Sneath and Sokal, 1973). Factor analysis was carried out through the DARWIN 5.0.155 program (Perrier et al., 2003) and also by adopting the DICE coefficient for the calculation of the genetic distances.

Morphological description of endocarps. For endocarp description, 11 characters were selected from the pomological pattern widely used for olive cultivar characterization (Barranco et al., 2005). They are described in Table 1.

\section{Results and Discussion}

Microsatellites diversity in the "Boughrara"Sfax germplasm collection. All accessions were screened for the eight selected microsatellite markers. Amplification products were obtained for the majority of them $(98.8 \%)$. In the remaining samples, amplification failure was observed in three accessions at GAPU 101 locus, two accessions at UDO99-43 locus, and only one accession at both ssrOeUA-DCA15 and ssrOeUADCA16 locus. Microsatellites showed a high level of polymorphism throughout the analyzed accessions and revealed the existence of 64 alleles. The number of alleles per locus ranged from five (ssrOeUA-DCA15 and GAPU71B loci) to 12 (UDO99-43 locus), with an average of eight alleles per locus (Table 2 ). Such a high average reveals the elevated level of variability within the "Boughrara"Sfax germplasm collection when compared with similar studies. The lower averages obtained in other studies can be explained by either the use of less polymorphic microsatellite markers (Belaj et al., 2004; Montemurro et al., 2005; Rekik et al., 2008) or by the use of less diversified plant material (Carriero et al., 2002; Noormohammadi et al., 2007). Higher averages have been reported by other workers (Baldoni et al., 2009; Taamalli et al., 2008) most likely as a consequence of using more diversified genotypes. The analysis of the distinctive endocarp characters also revealed high variability in the current study. The diversity in Tunisian olive germplasm has been already reported by using morphological and agronomical traits (Mehri et al., 1997; Trigui et al., 2002) and molecular analysis as well (Grati-Kamoun et al., 2006; Rekik et al., 2008; Taamalli et al., 2006, 2008).

Expected heterozygosity values ranged between 0.54 (ssrOeUA-DCA15) and 0.82 (UDO99-43) with an average of 0.68 , whereas $\mathrm{H}_{\mathrm{O}}$ varied from 0.31 (ssrOeUA-DCA15) to 0.96 (in both ssrOeUA-DCA18 and UDO9943 ) with an average of 0.77 (Table 2). Except for the ssrOeUA-DCA15 and ssrOeUA-DCA9 loci, $\mathrm{H}_{\mathrm{E}}$ was lower than $\mathrm{H}_{\mathrm{O}}$. In the case of the ssrOeUA-DCA15 and ssrOeUA-DCA9 loci, $\mathrm{H}_{\mathrm{E}}$ higher value of $\mathrm{H}_{\mathrm{O}}$ is most likely the result of the positive probability of null alleles $\left(\mathrm{F}_{0}=\right.$ 0.3 and $F_{0}=0.08$, respectively), whereas $F_{0}$ was negative in all the remaining cases. Null alleles usually exist when primers cannot anneal with DNA during PCR reaction as a result of point mutations (Pemberton et al., 1995 ) and thus it affects the estimated heterozygosis level in the correspondent locus. Positive null allele's frequencies have been also reported for the ssrOeUA-DCA15 locus by Baldoni et al. (2009) and Noormohammadi et al. (2007). Therefore, we recommend the mentioned marker to be discarded for further uses. The high $\mathrm{H}_{\mathrm{O}}$ average (0.77) confirms the important diversity among the "Boughrara"Sfax germplasm collection. Similar averages ( 0.74 and 0.62$)$ have been reported by Rekik et al. (2008) and Taamalli et al. (2008) in Tunisian cultivars.

Polymorphic information content (PIC) calculated from $\mathrm{H}_{\mathrm{E}}$ and allele frequencies showed an average value of 0.63 . This index ranged from 0.48 (ssrOeUA-DCA15) to 0.79 (UDO9943) (Table 2). Similar PIC values have been reported in other studies (Bandelj et al., 2004; Noormohammadi et al., 2007). Except for the ssrOeUA-DCA15, all PIC values were higher than 0.5 , which demonstrates the powerfulness of the markers. Two of them presented values over 0.7 ; hence, they can be considered particularly useful for genetic mapping (Bandelj et al., 2004). The results recently obtained by Baldoni et al. (2009), who recommend a consensus list of SSRs for worldwide olive

Table 2. Characteristics of the alleles observed after amplification with the eight simple sequence repeat combinations and different genetic indexes.

\begin{tabular}{|c|c|c|c|c|c|c|c|c|c|}
\hline & Size range & No. of alleles & No. of unique alleles & No. of allele patterns & $\mathrm{H}_{\mathrm{E}}^{\mathrm{z}}$ & $\mathrm{H}_{\mathrm{O}}^{\mathrm{y}}$ & $\mathrm{F}_{0}^{\mathrm{x}}$ & $\mathrm{PIC}^{\mathrm{w}}$ & $\mathrm{PI}^{\mathrm{v}}$ \\
\hline SsrOeUA-DCA18 & $166-180$ & 7 & 0 & 13 & 0.72 & 0.96 & -0.16 & 0.67 & 0.12 \\
\hline SsrOeUA-DCA3 & $228-249$ & 6 & 0 & 11 & 0.65 & 0.72 & -0.05 & 0.58 & 0.18 \\
\hline SsrOeUA-DCA15 & $241-264$ & 5 & 1 & 9 & 0.54 & 0.31 & +0.3 & 0.48 & 0.26 \\
\hline SsrOeUA-DCA16 & $120-172$ & 11 & 2 & 19 & 0.74 & 0.86 & -0.09 & 0.69 & 0.10 \\
\hline GAPU71B & $117-141$ & 5 & 0 & 11 & 0.66 & 0.91 & -0.17 & 0.60 & 0.17 \\
\hline SsrOeUA-DCA9 & $161-208$ & 11 & 1 & 16 & 0.60 & 0.52 & +0.08 & 0.56 & 0.19 \\
\hline GAPU101 & $183-217$ & 7 & 0 & 15 & 0.75 & 0.91 & -0.1 & 0.70 & 0.10 \\
\hline UDO99-43 & $166-214$ & 12 & 2 & 21 & 0.82 & 0.96 & -0.08 & 0.79 & 0.05 \\
\hline$\underline{\text { Mean }^{\mathrm{u}}}$ & - & 64 & 6 & 115 & 0.68 & 0.77 & - & 0.63 & 0.15 \\
\hline
\end{tabular}

${ }^{\mathrm{z}} \mathrm{H}_{\mathrm{E}}=$ expected heterozygosity.

${ }^{\mathrm{y}} \mathrm{H}_{\mathrm{O}}=$ observed heterozygosity.

${ }^{\mathrm{x}} \mathrm{F}_{0}=$ probability of null alleles.

${ }^{\mathrm{w}} \mathrm{PIC}=$ polymorphic information content

${ }^{\mathrm{v}} \mathrm{PI}=$ probability of identity.

"Number of alleles, unique alleles, and allele patterns are total. 
DNA typing, are in complete accordance with the current work. Seven of the eight SSRs used here for the analysis of "Boughrara"Sfax germplasm collection together with the GAPU103A (not used in this work) are currently considered the most reliable markers for olive cultivar discrimination and for population genetic studies (Baldoni et al., 2009).

Discrimination and identification of Tunisian cultivars in the germplasm collection. The probability of identity (PI) can be considered as an index of the microsatellite discriminative power. In the present study, it ranged from 0.05 (UDO99-43) to 0.26 (ssrOeUA-DCA15) with an average of 0.15
(Table 2). In a similar study, Noormohammadi et al. (2007) obtained a higher average $(0.19)$ for this index because they used a less discriminative set of microsatellites. In the current work, the cumulative PI value was $1.2310^{-7}$, which confirms the high discriminative level of the used microsatellite set. UDO99-43, GAPU101 ssrOeUA-DCA16, and ssrOeUA-DCA18 were the most informative markers (cumulative PI: $7.6 \quad 10^{-5}$ ). They were able by themselves to discriminate $82.5 \%$ of the whole genotypes identified by the eight microsatellites altogether. UDO9943 alone allows the discrimination of 21 genotypes, which means $52.5 \%$ of the entire identified genotypes. The mentioned marker showed a very low probability of identity (5. $\left.10^{-2}\right)$. It can be considered the most powerful marker used in this work. The same observation has been reported by other workers (Baldoni et al., 2009; Belaj et al., 2004; Noormohammadi et al., 2007) and thus UDO99-43 is a highly recommended marker for olive cultivar discrimination.

Numerous duplications (44) were observed within the "Boughrara"-Sfax germplasm collection, whereas only 40 genotypes were identified among the 84 analyzed accessions (Table 3 ). The highest number of duplications (30) was detected regarding the

Table 3. Accessions studied, geographical origin, and proposed denominations.

\begin{tabular}{|c|c|c|c|c|c|c|c|}
\hline Accession name & Origin & Diffusion level & Proposed name & Accession name & Origin & Diffusion level & Proposed name \\
\hline Chemlali Sfax ${ }^{z}$ & Sfax & Primary & Chemlali Sfax & Injassi Hchichina & Sfax & Secondary & Injassi Hchichina \\
\hline Chemlali Sfax COI & Sfax & Primary & Chemlali Sfax & Chemlali Mahares ${ }^{\mathrm{r}}$ & Sfax & Secondary & Injassi Hchichina \\
\hline Sig $3 P G$ & Sfax & Primary & Chemlali Sfax & Chétoui 2 & Tunis & Primary & Chetoui \\
\hline Baldi Charqia BL8 ${ }^{v}$ & Sfax & Primary & Chemlali Sfax & Chétoui 2 à mam & Tunis & Primary & Chetoui \\
\hline BL24 & Sfax & Primary & Chemlali Sfax & Marsaline & Tunis & Primary & Marsaline \\
\hline Kotti K18 & Sfax & Primary & Chemlali Sfax & Meski Bjawa ${ }^{q}$ & Tunis & Primary & Marsaline \\
\hline CHL Ouled Youssef Sig 13 & Sfax & Primary & Chemlali Sfax & Fakhari Tataouine & Tataouine & Primary & Fakhari Tataouine \\
\hline Hchichina 10 & Sfax & Primary & Chemlali Sfax & Meski Zarzis ${ }^{\mathrm{p}}$ & Mednine & Primary & Fakhari Tataouine \\
\hline Sehli Sned $7^{\mathrm{v}}$ & Gafsa & Primary & Chemlali Sfax & Chemlali Chouamekh ${ }^{z}$ & Mednine & Primary & Chemlali Chouamekh \\
\hline Kotti K12 & Sfax & Primary & Chemlali Sfax & Chemlali Tataouine $10^{\circ}$ & Tataouine & Primary & Chemlali Chouamekh \\
\hline K17 & Sfax & Primary & Chemlali Sfax & Chemlali Sigz & Sfax & Secondary & Chemlali Sig \\
\hline Hchichina 6 & Sfax & Primary & Chemlali Sfax & Kotti K14 & Sfax & Secondary & Chemlali Sig \\
\hline BL26 & Sfax & Primary & Chemlali Sfax & Sig 14 PG & Sfax & Secondary & Chemlali Sig \\
\hline Chemlali Bjawav $^{v}$ & Tunis & Primary & Chemlali Sfax & Besbessi & Tunis & Primary & Besbessi \\
\hline Zalmati Zarzis ${ }^{\mathrm{v}}$ & Mednine & Primary & Chemlali Sfax & Lattout Sned 3 & Gafsa & Primary & Lattout Sned \\
\hline Sig 15 & Sfax & Primary & Chemlali Sfax & CHL Sig $12 \mathrm{PG}^{\mathrm{z}}$ & Sfax & Tertiary & Horr Sig \\
\hline Sehli Gafsa Dawla1 ${ }^{v}$ & Gafsa & Primary & Chemlali Sfax & $\begin{array}{c}\text { Chemlali Ontha } \\
\text { Tataouine }^{z}\end{array}$ & Tataouine & Secondary & $\begin{array}{c}\text { Chemlali Ontha } \\
\text { Tataouine }\end{array}$ \\
\hline BL23 & Sfax & Primary & Chemlali Sfax & Chemlali Bouchouka $^{z}$ & Sfax & Tertiary & Chemlali Bouchouka \\
\hline BL20 & Sfax & Primary & Chemlali Sfax & Horr Louzir BL32 PG & Sfax & Tertiary & Horr Louzir \\
\hline Horr Sfax ${ }^{v}$ & Sfax & Primary & Chemlali Sfax & Chahla $^{\mathrm{y}}$ & Sfax & Tertiary & Chahleya \\
\hline BL16 G & Sfax & Primary & Chemlali Sfax & Semni Jbeniana Sig 0 & Sfax & Tertiary & Semni Jbeniana \\
\hline Hchichina 7 & Sfax & Primary & Chemlali Sfax & Jeddaria Chaal & Sfax & Tertiary & Jeddaria Chaal \\
\hline Kotti K9G & Sfax & Primary & Chemlali Sfax & $\begin{array}{l}\text { Mallahi El Mouammar } \\
\quad \text { Sig } 1 \mathrm{G}\end{array}$ & Sfax & Tertiary & Mallahi El Mouammar \\
\hline Kotti k21 & Sfax & Primary & Chemlali Sfax & Tounsi Gafsa & Gafsa & Secondary & Tounsi Gafsa \\
\hline Kotti K30G & Sfax & Primary & Chemlali Sfax & Autre Zarrazi ${ }^{\mathrm{w}}$ & Mednine & Secondary & Zarrazi Ejjbal \\
\hline Sig $113 \mathrm{G}$ & Sfax & Primary & Chemlali Sfax & Ech-Chahla/g ${ }^{\mathrm{y}}$ & Sfax & Tertiary & Ech-Chahla \\
\hline $\begin{array}{l}\text { Sehli JbenianaBL15 } \\
\text { Bent Louzir }\end{array}$ & Sfax & Primary & Chemlali Sfax & Neb Tataouine & Tataouine & Secondary & Neb Tataouine \\
\hline BL37 & Sfax & Primary & Chemlali Sfax & Kotti K9 PG & Sfax & Tertiary & Horr El Kotti \\
\hline Chemlali Ouled Youssef ${ }^{\mathrm{v}}$ & Sfax & Primary & Chemlali Sfax & Lqam El Kotti Kotti K3 & Sfax & Tertiary & Lqam El Kotti \\
\hline Sahli Gafsa autre que Gtarv & Gafsa & Primary & Chemlali Sfax & Kotti K56 G & Sfax & Tertiary & Horr El Mouammar \\
\hline Horr Blettech BL11 PG & Sfax & Primary & Chemlali Sfax & Chemlali Barrani $^{z}$ & Mednine & Secondary & Chemlali Barrani \\
\hline Khechinet Sig & Sfax & Secondary & Khechinet Sig & K56PG & Sfax & Tertiary & Lqam El Mouammar \\
\hline SIG19 & Sfax & Secondary & Khechinet Sig & Chemlali Balhiz $^{z}$ & Mednine & Secondary & Chemlali Balhi \\
\hline Bou Bazzoula BL19PG ${ }^{u}$ & Sfax & Secondary & Khechinet Sig & Sig $112 \mathrm{PG}$ & Sfax & Tertiary & Zeitoun Khdim El Bey \\
\hline Kotti K23 (avec mam) & Sfax & Secondary & Khechinet Sig & Zeitoun Boubazzoula $\mathrm{COI}^{\mathrm{x}}$ & Sfax & Tertiary & Zeitoun Boubazzoula \\
\hline BL2 & Sfax & Tertiary & Horr Charqia & Kotti K32 & Sfax & Tertiary & Zeitoun El Manacher \\
\hline BL31 & Sfax & Tertiary & Horr Charqia & BL32 G & Sfax & Tertiary & Chemlali Lach'hab \\
\hline Chemlali Zarzis ${ }^{z}$ & Mednine & Primary & Chemlali Zarzis & Zarrazi Kgh ${ }^{\mathrm{w}}$ & Mednine & Primary & Zarrazi Kgh \\
\hline Mfartah Hchichina $\mathrm{H}^{\mathrm{t}}$ & Sfax & Primary & Chemlali Zarzis & Zeitoun Boubazzoula COI & Sfax & Secondary & Mbazzel Kbir \\
\hline Jemri Bouchouka & Tataouine & Primary & Jemri Bouchouka & Dhokar Nafti & Mednine & Secondary & Dhokar Nafti \\
\hline Chemchali Gtar $3^{\text {s }}$ & Gafsa & Primary & Jemri Bouchouka & Zarbout Louzir & Sfax & Secondary & Zarbout Louzir \\
\hline Kotti K30 PG & Sfax & Primary & Jemri Bouchouka & Kotti K11 & Sfax & Tertiary & Zeyeti El Kotti \\
\hline
\end{tabular}

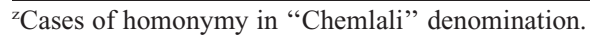

"Cases of homonymy in "Chahla" denomination.

${ }^{\mathrm{x}}$ Cases of homonymy in "Zeitoun Boubazzoula" denomination.

"Cases of homonymy in "Zarrazi" denomination.

${ }^{\mathrm{v}}$ Cases of synonymy in Chemlali Sfax cultivar.

"Case of synonymy in Khechinet Sig cultivar.

${ }^{\mathrm{t}}$ Case of synonymy in Chemlali Zarzis cultivar.

${ }^{\text {s}}$ Case of synonymy in Jemri Bouchouka cultivar.

${ }^{\mathrm{r}}$ Cases of synonymy of Injassi Hchichina cultivar.

${ }^{\mathrm{q}}$ Case of synonymy of Marsaline cultivar.

${ }^{\mathrm{p} C}$ Case of synonymy of Fakhari Tataouine cultivar.

${ }^{\circ}$ Case of synonymy of Chemlali Chouamekh cultivar. 
'Chemlali Sfax' genotype explained by the wide distribution of this cultivar across the country.

The identification achieved in the present work is extremely important for better management of the "Boughrara"-Sfax germplasm collection. Furthermore, it can be useful for providing a well-identified material to olive nurseries.

Synonyms and homonyms. Several cases of synonyms (different denomination for the same genotype) and homonyms (same denomination for different genotype) were detected in the collection. The highest number of synonyms (nine) was also observed in the cultivar Chemlali Sfax, which is the most widely cultivated in the southern part of the country. Moreover, our results showed that 'Chemlali Sfax' synonyms exist in the majority of the olive-producing regions of Tunisia (Sfax, Gafsa, Mednine, and Tunis) with different denominations (Table 3). Among them, "Sehli Sned," "Sehli Gafsa," and "Sehli Jbeniana Bent Louzir" accessions are associated with the same adjective "Sehli" (which means "olive from the coast"). The remaining cases of synonymy are represented in
Table 3. Similar cases of synonymy have been reported in Tunisian cultivars belonging to different collections and olive groves (Rekik et al., 2008; Taamalli et al., 2008). Endocarp characters displayed low variability among all duplicated profiles (Fig. 1). This scarce variability is most likely the result of the influences of the field and tree conditions (nutrition, water and phytosanitary status, etc.). However, more clear differences were revealed in all the endocarp characters analyzed between these individuals identified as independent genotypes.

On the other hand, a typical case of homonymy among Tunisian olive groves is that of "Chemlali," which has been reported by morphological, agronomical, and molecular studies (Grati-Kamoun et al., 2006; Mehri et al., 1997; Rekik et al., 2008; Taamalli et al., 2008; Trigui et al., 2002). This homonymy was also observed within the "Boughrara"Sfax germplasm collection. In fact, "Chemlali" is a common and general denomination used by growers, although it has been reported that a high level of polymorphism exists within this denomination. The present work

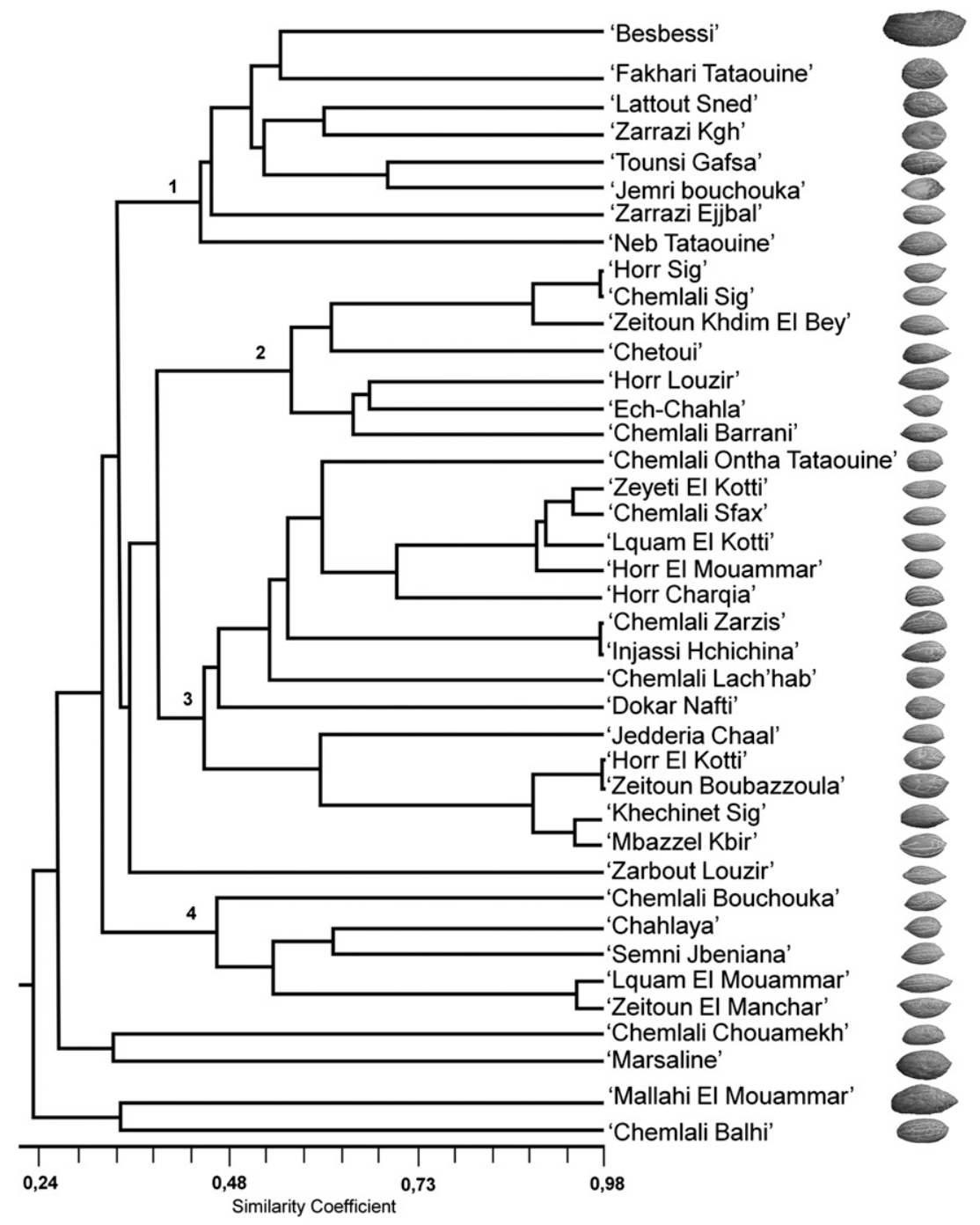

Fig. 1. Dedrogram of the identified cultivars based on DICE coefficient and unweighted pair group method with arithmetic mean (UPGMA) cluster analysis of the simple sequence repeat (SSR) data obtained. A picture of a representative endocarp is included for each accession. demonstrates that polymorphism among this denomination is extremely high. In some cases, only one of 16 alleles was shared between homonymous cultivars such as 'Chemlali Sfax' and 'Chemlali Balhi'. Several others cases of homonymy were detected in the collection (Table 3). Homonymous confusions are basically the result of the traditional denomination system. Cultivar names are mostly based on generic denominations like "Injassi" (pear form) or "Dhokar" (pollinator), etc. Similar cases have been reported in other olive-producing countries after using molecular markers (Belaj et al., 2001; Khadari et al., 2003; Mekuria et al., 1999; Noormohammadi et al., 2007; Trujillo et al., 2005). Homonyms were analyzed using endocarp morphology as the criteria. As an example, high variability in endocarp characteristics was detected particularly within Chemlali's denominations, in which the form and symmetry of the endocarp showed conspicuous differences as well as the form of the base, the roughness of the surface, and the number and distribution of vascular bundle over the surface.

Genetic relationships. Genetic relationships between identified genotypes were studied by means of the DICE coefficient. All duplicated samples were discarded from the analysis. The highest value of cophenetic coefficient (0.75) was obtained using the UPGMA clustering method. Therefore, the mentioned method was adopted as the most appropriate for further clustering (Fig. 1). DICE coefficient ranged from 0.0 (between cultivars like Mallahi El Mouammar and Chemlali Ontha Tataouine) to 0.96 (between 'Horr El Kotti' and 'Zitoun Boubazzoula'). The dendrogram demonstrated the presence of four major groups, five cultivars widely separated, and several very similar genotypes. Group 1 contains eight clearly discriminated genotypes. The second cluster was formed by seven genotypes, including the cultivar Chetoui, the second most widely distributed cultivar in Tunisia. 'Chetoui' was clearly separated within the cluster (0.61 DICE coefficient with 'Zeitoun Khdim El Bey', the closest cultivar). Two genotypes of this group ('Horr Sig' and 'Zeitoun Khdim El Bey') were very similar to 'Chemlali Sig' with DICE coefficients higher than 0.85 . The third cluster was the most important in terms of genotype number (15 genotypes). It included the widely distributed cultivar, Chemlali Sfax, which is situated close to three genotypes with DICE similarity coefficients higher than 0.92 ('Zeyeti El Kotti', 'Lqam El Kotti', and 'Horr El Mouammar'). The fourth cluster included five genotypes. Two of them ('Lquam El Mouammar' and 'Zeitoun El Manchar') presented a DICE coefficient close to 0.93 . Other workers have also reported such a high level of similarity between olive cultivars from several regions of the world (Belaj et al., 2004; Montemurro et al., 2005; Noormohammadi et al., 2007) and also among Tunisian cultivars (Rekik et al., 2008). These and other studies support the idea of these genotypes being considered as independent cultivars, although similarity 


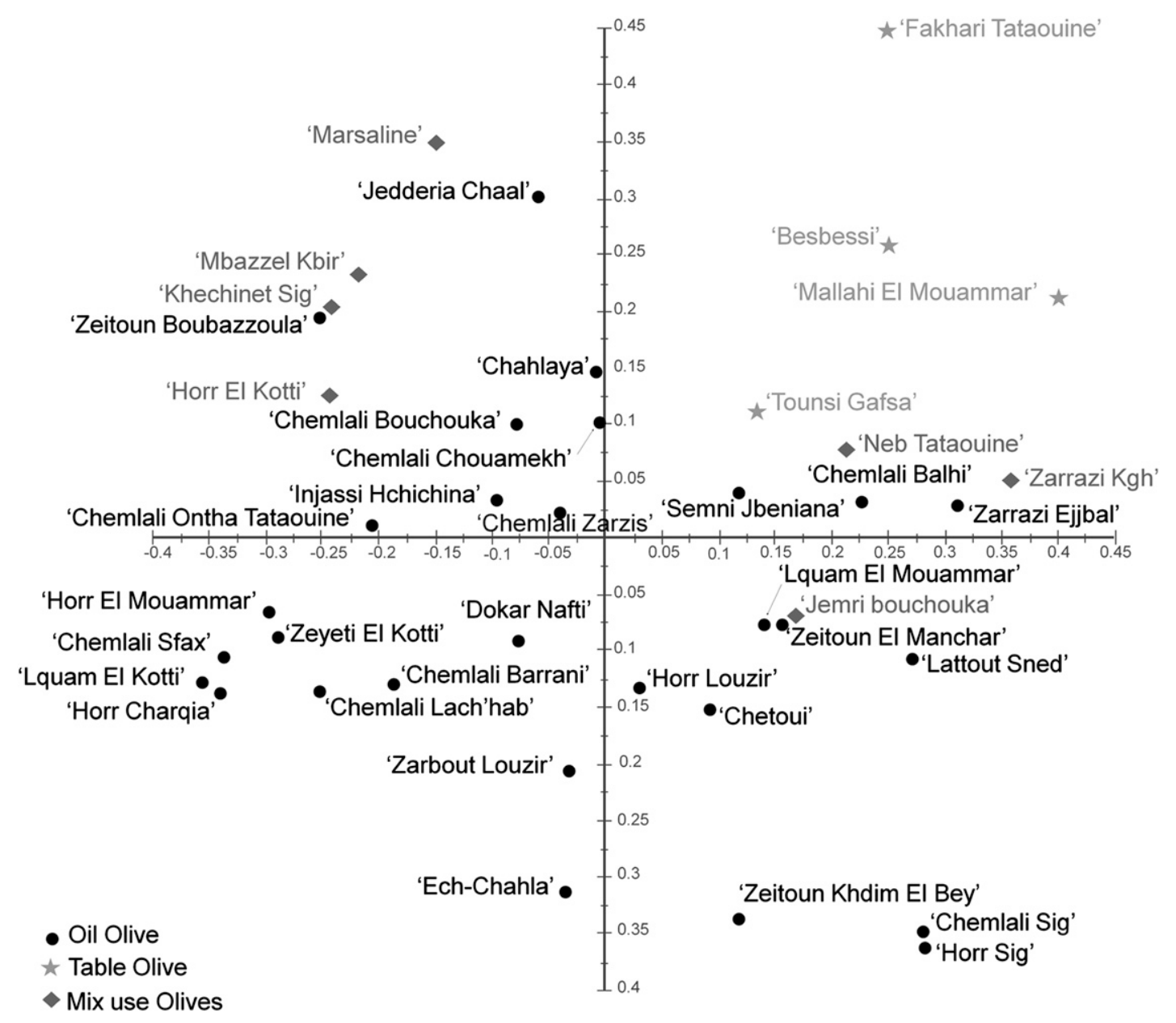

Fig. 2. Factor analysis of the identified genotypes according to their main uses.

among them is relatively high. In fact, microsatellites, as low proportions of the genome, were unable to detect intracultivar polymorphism as a result of mutations occurring in very long-living trees asexually propagated (Baldoni et al., 2009). This proposal is supported by previous agronomical observations within the collection.

On the other hand, the five cultivars Zarbout Louzir, Chemlali Chouamek, Marsaline, Mallahi El Mouammar, and Chemlali Balhi were clearly separated and distant from any other observed clusters. This can be attributed to their different origins. For example, Marsaline is a French cultivar, whereas the denomination 'Mallahi El Mouammar', which can be translated as "settler's table olive," is most likely a foreign cultivar. The morphological characters of the endocarps were in accordance with the dendrogram of the genetic relationship shown here (Fig. 1). For example, only very small differences were detected between Horr Sig and Chemlali Sig cultivars, which showed a high coefficient of DICE similarity (0.96). On the contrary, wide morphological differences were observed between the endocarps of 'Mallahi El Mouammar' and 'Chahleya' (with DICE coefficient 0.27).

Finally, factor analysis has been conducted to characterize clustering tendencies among the identified cultivars (Fig. 2). The analysis revealed only $16.38 \%$ and $12.14 \%$ of clustering according to two principal components. Such low percentages only allow considering the clustering as tendencies and not as clear separations. The test ended with the clustering of the four olive table cultivars altogether. This is probably a result of Tunisian growers' selections during the olive cultivation history of the country. The selection has been made according to producer requirements, genotypes intended for table olive consumption, and others for olive oil and mixture uses. However, no clustering tendencies were reported according to the cultivar's geographical origin, probably as the result of the land continuity between oliveproducing regions, which promoted the genetic exchange (data not shown). Cultivar clustering in accordance to the geographical area of cultivation has been reported by different authors (Besnard et al., 2001b; Claros et al., 2000; Fabbri et al., 1995). However, it is not generally observed, even using powerful genetic markers like SSRs, except in those regions where the genetic exchange has been very limited.

In conclusion, the total number of alleles, the number of allele per locus, and the $\mathrm{H}_{\mathrm{O}}$ demonstrate the high genetic diversity in the "Boughrara"-Sfax germplasm collection located in Tunisia. A high number of mislabeled accessions and several synonymous and homonymous cases were reported. These results put emphasis on the necessity of an improved classification within this collection, containing a very important part of the Tunisian olive genetic resources.

With the exception of ssOeUA-DCA15, all the microsatellites used confirmed to be reliable for olive cultivar classification in a germplasm collection. Therefore, the set used here can be recommended for DNA fingerprinting in other Tunisian collections and thus contribute to the establishment of a universal molecular database of olive genetic resources based on standard SSR markers as proposed by Baldoni et al. (2009).

The results of the SSR classification were in good agreement with the differences observed after analyzing morphological characters of the endocarps. We therefore suggest that the incorporation of both approaches is extremely advisable for accurate characterization of olive germplasm.

\section{Literature Cited}

Angiolillo, A., M. Mencuccini, and L. Baldoni. 1999. Olive genetic diversity assessed using amplified fragment length polymorphisms. Theor. Appl. Genet. 98:411-421.

Baldoni, L., N.G. Cultrera, R. Mariotti, C. Ricciolini, S. Arcioni, G. Vendramin, A. Buonamici, A. Porceddu, V. Sarri, M. Ojda, I. Trujillo, L. Rallo, A. Belaj, E. Perri, A. Salimonti, I. Muzzalupo, A. Casagrande, O. Lain, R. Messina, 
and R. Testolin. 2009. A consensus list of microsatellite markers for olive genotyping. Mol. Breed. 24:213-231.

Bandelj, D., J. Jakse, and B. Javornik. 2004. Assessment of genetic variability of olive variety by microsatellite and AFLP markers. Euphytica 136:93-102.

Barranco, D., A. Cimato, P. Fiorino, L. Rallo, A Touzani, C. Castañeda, F. Seraf ín, and I. Trujillo. 2000. World catalogue of olive varieties. Internacional Olive Oil Council, Madrid, España.

Barranco, D. and L. Rallo. 1984. Las variedades de olivo cultivadas en Andalucía. M. ${ }^{\circ}$ de agricultura. Junta de Andalucía, Madrid, Spain.

Barranco, D., I. Trujillo, and L. Rallo. 2005. Libro I Elaiografía Hispánica, p. 45-231. In: Rallo, L., D. Barranco, J.M. Caballero, C. Del Rio, A Martin, J. Tous, and I. Trujillo (eds.). Variedades de olivo en España. Junta de Andalucía. MAPA y Ediciones Mundi-Prensa, Madrid, Spain.

Belaj, A., G. Cipriani, R. Testolin, L. Rallo, and I. Trujillo. 2004. Characterization and identification of the main Spanish and Italian olive cultivars by simple-sequence-repeat-markers. HortScience 39:1557-1561.

Belaj, A., I. Trujillo, R. De la Rosa, L. Rallo, and M.J. Giménez. 2001. Polymorphism and discriminating capacity of randomly amplified polymorphic markers in an olive germplasm bank. J. Amer. Soc. Hort. Sci. 126:64-71.

Besnard, G., P. Batadat, D. Chevalier, A. Tagmount, and A. Bervillé. 2001a. Genetic differentiation in the olive complex (Olea europaea) revealed by RAPDs and RFLPs in the rRNA genes. Genet. Resources Crop Evol. 48:165-182.

Besnard, G., P. Baradat, and A. Berville. 2001b. Genetic relationships in the olive (Olea europaea L.) reflect multilocal selection of cultivars. Theor. Appl. Genet. 102:251-258.

Botstein, D., R.L. White, M. Skolnick, and R.W. Davis. 1980. Construction of a genetic linkage map in man using restriction fragment length polymorphisms. Am. J. Hum. Genet. 32:314-331.

Caballero, J.M., C. Del Rio, D. Barranco, and I. Trujillo. 2006. The Olive World Germplasm Bank of Córdoba, Spain. Olea. 25:14-19.

Carriero, F., G. Fontanazza, F. Cellini, and G. Giorio. 2002. Identification of simple sequence repeats (SSRs) in olive (Olea europaea L.). Theor. Appl. Genet. 104:301-307.

Cimato, A., C. Cantini, G. Sani, and M. Marranci. 1993. II Germoplasma dell' Olivo in Toscana. Ed., Regione Toscana, Florence, Italy, p. 1254

Cipriani, G., M.T. Marrazzo, R. Marconi, A. Cimato, and R. Testolin. 2002. Microsatellite markers isolated in olive are suitable for individual fingerprinting and reveal polymorphism within ancient cultivars (Olea europaea L.). Theor. Appl. Genet. 104:223-228.

Claros, M.G., R. Crespillo, M.L. Aguilar, and F.M. Canovas. 2000. DNA fingerprinting and classification of geographical related genotypes of olive tree (Olea europaea L.). Euphytica 116:131-142.

De la Rosa, R., C. James, and K.R. Tobutt. 2002. Isolation and characterization of polymorphic microsatellites in olive (Olea europaea L.) and their transferability to other genera in the Oleacea. Mol. Ecol. Notes 2:265-267.

Fabbri, A., J.I. Hormaza, and V.S. Polito. 1995. Random amplified polymorphic DNA analysis of olive (Olea europaea L.) cultivars. J. Amer. Soc. Hort. Sci. 120:538-542.
Grati-Kamoun, N., F. Lamy Mahmoud, A. Rebai, A. Gargouri, O. Panaud, and A. Saar. 2006. Genetic diversity of Tunisian olive tree (Olea europaea L.) cultivars assessed by AFLP markers. Genet. Resources Crop Evol. 53:265-275.

Hannachi, H., C. Breton, M. Msallem, S. Ben El Hadj, M. El Gazzah, and A. Bervillé. 2008. Differences between native and introduced olive cultivars as revealed by morphology of drupes, oil composition and SSR polymorphisms: A case study in Tunisia. Sci. Hort. 116: 280-290.

International Olive Council. 2010. Survey and assessment division. 14 Apr. 2010. <http:// www.internationaloliveoil.org/>.

Jardak, T. 2006. The olive industry in Tunisia Proc. II Int. Sem. Olivebioteq. Mazara del Vallo (TP), 5-10 Nov. 2006. p. 35-46.

Khadari, B., C. Breton, N. Moutier, J.P. Roger, G. Besnard, A. Bervillé, and F. Dosba. 2003. The use of molecular markers for germplasm management in a French olive collection. Theor. Appl. Genet. 106:521-529.

La Mantia, M., O. Lain, T. Caruso, and R. Testolin. 2005. SSR-based DNA fingerprints reveal the genetic diversity of Sicilian olive (Olea europaea L.) germplasm. J. Hort. Sci. Biotechnol. 80:628-632.

Marshall, T.C., J. Slate, L.E.B. Kruuk, and J.M Pemberton. 1998. Statistical confidence for likelihood-based paternity inference in natural populations. Mol. Ecol. 7:639-655.

Mehri, H., M. M'sallem, and R. Kamoun-Mehri. 1997. Identification des principaux cultivars d'olivier cultivés en Tunisie. Plant Genet. Resour. Newsl. 112:68-72.

Mekuria, G.T., G.G. Collins, and M. Sedgley. 1999. Genetic variability between different accessions of some common commercial olive cultivars. J. Hort. Sci. Biotechnol. 74:309314.

Montemurro, C., R. Simeone, A. Pasqualone, E. Ferrara, and A. Blanco. 2005. Genetic relationships and cultivar identification among 112 olive accessions using AFLP and SSR markers. J. Hort. Sci. Biotechnol. 80:105-110.

Murry, M.G. and W.F. Tompson. 1980. Rapid isolation of high molecular weight plant DNA. Nucleic Acids Res. 8:4321-4325.

Muzzalupo, I., N. Lombardo, A. Musacchio, M.E. Noce, G. Pellegrino, E. Perri, and A. Sajjad. 2006. DNA sequence analysis of microsatellite markers enhances their efficiency for germplasm management in an Italian olive collection. J. Amer. Soc. Hort. Sci. 131:352359.

Nei, M. 1987. Genetic distance and molecular phylogeny, p. 193-223. In: Ryman, N. and F. Utter (eds.). Population genetics and fishery management. University of Washington Press, Seattle, WA.

Noormohammadi, Z., M. Hosseini-Mazinani, I. Trujillo, L. Rallo, A. Belaj, and M. Sadeghizadeh. 2007. Identification and characterization of main Iranian olive cultivars using microsatellite markers. HortScience 42:1545-1550.

Ouazzani, N., R. Lumaret, P. Villemur, and F. Di Giusto. 1993. Leaf allozyme variation in cultivated and wild olive trees (Olea europaea L.). J. Hered. 84:34-42.

Pemberton, J.M., J. Slate, D.R. Bancroft, and J.A. Barrett. 1995. Non-amplifying alleles at micro- satellite loci: A caution for parentage and population studies. Mol. Ecol. 4:249-252.

Perrier, X., A. Flori, and F. Bonnot. 2003. Data analysis methods, p. 43-76. In: Hamon, P., M. Seguin, X. Perrier and J.C. Glaszmann (eds.). Genetic diversity of cultivated tropical plants. Enfield, Sci. Publishers, Montpellier, VT.

Rafalski, J.A., J.M. Vogel, M. Morgante, W. Powell, C. Andre, and S.V. Tingey. 1996. Generating and using DNA markers in plants, p. 75-134. In: Birren, B. and E. Lai (eds.). No mammalian genomic analysis. A practical guide. Academic Press, San Diego, CA.

Rallo, L., D. Barranco, J.M. Caballero, C. Del Rio, A. Martin, J. Tous, and I. Trujillo (eds.). 2005. Variedades de olivo en España. Junta de Andalucía. MAPA y Ediciones Mundi-Prensa, Madrid, Spain.

Rekik, I., A. Salimonti, N. Grati-Kamoun, I. Muzzalupo, E. Perri, and A. Rebai. 2008. Characterisation and identification of Tunisian olive tree varieties by microsatellite markers. HortScience 43:1371-1376.

Rohlf, F.J. 1998. NTSYS-pc. Numerical taxonomy and multivariate analysis system. Version 2.00. Exeter Software Publishers Ltd., Setanket, NY.

Sefc, K.M., M.S. Lopes, D. Mendonca, M. Rodrigues Dos Santos, M. Laimer Da Câmara Machado, and A. Da Câmara Machado. 2000. Identification of microsatellite loci in olive (Olea europaea L.) and their characterization in Italian and Iberian olive trees. Mol. Ecol. 9: 1171-1193.

Sneath, P.H.A. and R.R. Sokal. 1973. Numerical taxonomy, p. 513. In: W.H. Freeman and Co. (eds.). The principles and practice of numerical taxonomy. MathSciNet, San Francisco, CA.

Taamalli, W., F. Geuna, R. Banfi, D. Bassi, D. Daoud, and M. Zarrouk. 2006. Agronomic and molecular analyses for the characterisation of accessions in Tunisian olive germplasm collections. Electron. J. Biotechnol. 5:468-481.

Taamalli, W., F. Guena, D. Bassi, D. Daoud, and M. Zarrouk. 2008. SSR marker based fingerprinting of Tunisian olive (Olea europaea L.) varieties. J. Agron. 7:176-181.

Trigui, A., M. Msallem, A. Yengui, H. Belguith, J Khecherem, A. Meliène, S. Malek, A. Bousselmi, A. Samet, and E.B. Trabelsi. 2002. Oliviers de Tunisie (1). Ministère de l'Agriculture IRESA, Institut de l'Olivier, Republique Tunisienne.

Trigui, A., A. Yengui, and H. Belguith. 2006. Olive germplasm in Tunisia. Olea. 25:19-23.

Trujillo, I., A. Morales, A. Belaj, V. Valpuesta, M.A. Botella, P. Rallo, A. Martín, and G. Dorado. 2005. Libro III Mejora genética y biotecnología, p. 405-471. In: Rallo, L., D. Barranco, J.M. Caballero, C. Del Rio, A. Martin, J. Tous, and I. Trujillo (eds.). Variedades de olivo en España. Junta de Andalucía. MAPA y Ediciones Mundi-Prensa, Madrid, Spain.

Trujillo, I., L. Rallo, and P. Arus. 1995. Identifying olive cultivars by isozyme analysis. J. Amer. Soc. Hort. Sci. 120:318-324.

Valiere, N. 2002. GIMLET: A computer program for analysing genetic individual identification data. Mol. Ecol. Notes 2:377-379.

Waits, L.P., G. Luikart, and P. Taberlet. 2001. Estimating the probability of identity among genotypes in natural populations: Cautions and guidelines. Mol. Ecol. 10:249-256. 